\section{TERET A FOLYÓKNAK! \\ A NAGYVÍZI MEDERKEZELÉS \\ SZEREPE A HAZAI ÁRVÍZVÉDELEMBEN}

Láng István (okl. vízépitömérnök, az Országos Vizügyi Föigazgatóság müszakiföigazgató-helyettese), lang.istvan@ovf.hu

\section{ÖSSZEFOGLALÓ}

Magyarország területének közel 25 százaléka árvízszintek alatt fekszik. Főként a klímaváltozás és a helytelen területhasználatok következtében az árvízszintek ma már mintegy 1,5-2 méterrel haladják meg a 20. század derekáig észlelt maximumokat. Alapvető érdekünk ennek a folyamatnak a lassítása, megállítása. A hagyományos árvízvédelmi módszerek lehetőségei kimerültek. Az újak közül a legfontosabb a folyók árvízlevezető képességének a helyreállítása. Erre szolgálnak az úgynevezett nagyvízi mederkezelési tervek. Hatásukra csökkenhet az árvizek szintje, csökkennek az árvízi károk, a folyó és az emberi tevékenységek kapcsolata normalizálódik, a mai veszélyhelyzet-elhárítási attitűd megelőző jellegűvé válik. Célszerű lenne a biztosítási szakma és a műszaki-hidrológiai megfontolások közötti párbeszéd a gazdasági szabályozás és ösztönzés korszerüsítésére.

\section{SUMMARY}

Approximately $25 \%$ of the Hungarian territory is located below flood level. It is mainly due to the climate change and inappropriate land use that nowadays the flood levels exceed that of the 20th century by 1.5-2 meters. It is our fundamental interest to slow down or to stop these tendencies. The options of the conventional flood protection methods are exhausted. The most important of the new types of measures are focusing on to restore flood capacity of the river. The so called floodplain management plans serve this purpose. The floodplain management plans can decrease the flood levels, flood damages, and the relationship between human and river will be normalized, the current emergency control attitude can become a preventive approach. It would be expedient to have a dialogue between the insurance profession and the technical-hydrological considerations for the sake of upgrading the economical regulation and incentives.
Kulcsszavak: árvízszint, kockázat, árvíz-megelőzés, levezető képesség, biztosítás Keywords: flood level, risk, flood prevention, convenience capacity, insurance

\section{JEL: H81, H83}

DOI: $10.18530 /$ BK.2017.2.42

http://dx.doi.org/1018530/BK.2017.2.42

\section{Adottságaink, folyamatok}

Hazánk a Duna 801 ezer km² kiterjedésű vízgyűjtő területén, a Kárpát-medence nagyrészt síkvidéki területén, a vízgyüjtő középpontjában fekszik (1. ábra). A Fekete-erdőtől a Fekete-tengerig tartó közel háromezer kilométeres útján tizenkilenc ország területéről gyüjti össze a vizét a Duna, ezzel a világ legnemzetközibb folyama. Minden, ami felettünk történik, tükröződik a Dunában, legyen az a víz minősége, mennyisége, hordaléka vagy élővilága. Kitettségünket jelzi, hogy hét országgal vagyunk határosak, és ebből négy ország vonatkozásában alvízi országként.

1. ábra: A Kárpát-medence árvízjárta területei a vízszabályozások elött

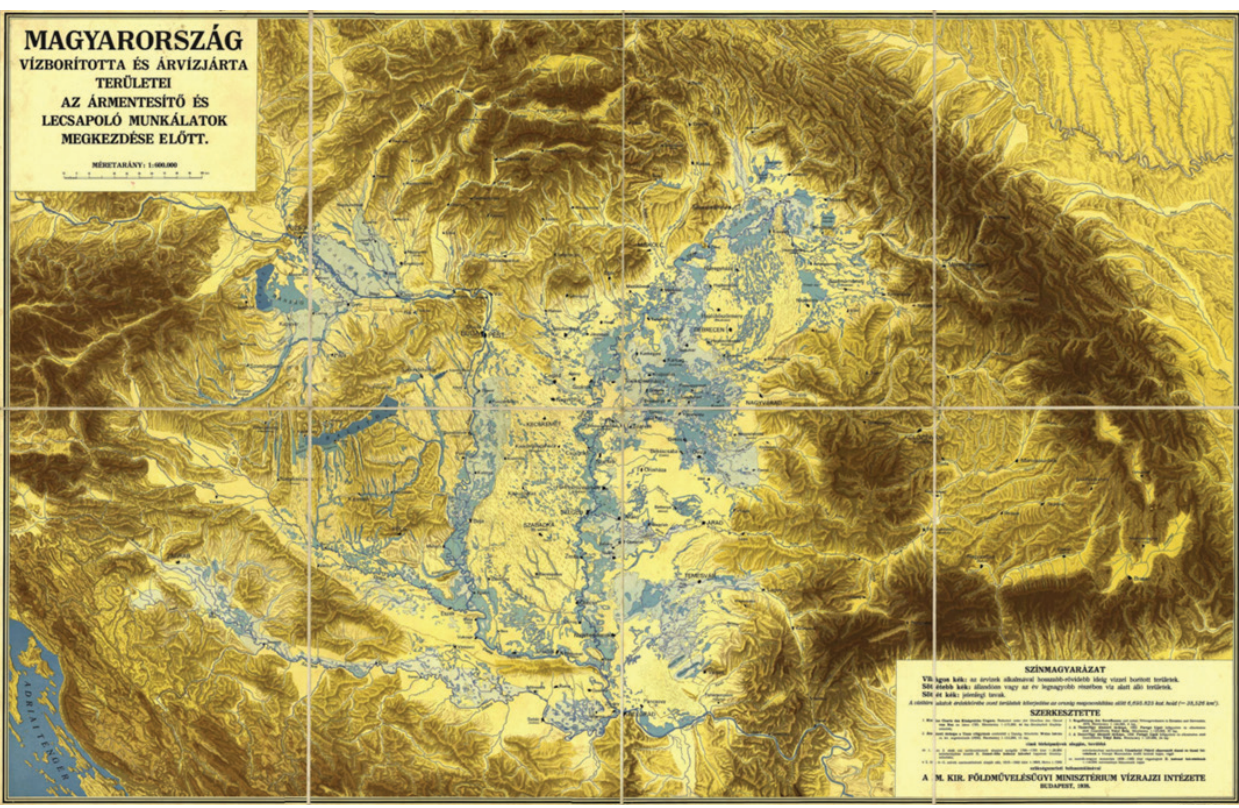

Forrás: Vízrajzi Intézet 1936 
A Kárpátok ívéről lefutó vizek a síkságra érve lelassulnak, összetorlódnak, és főként emiatt az ország területének negyedét árvizek veszélyeztetik (2.ábra). A veszélyeztetett terület aránya az európai országok között hazánkban a legnagyobb.

2. ábra: Nagy árvízvédelmi rendszerek Európában

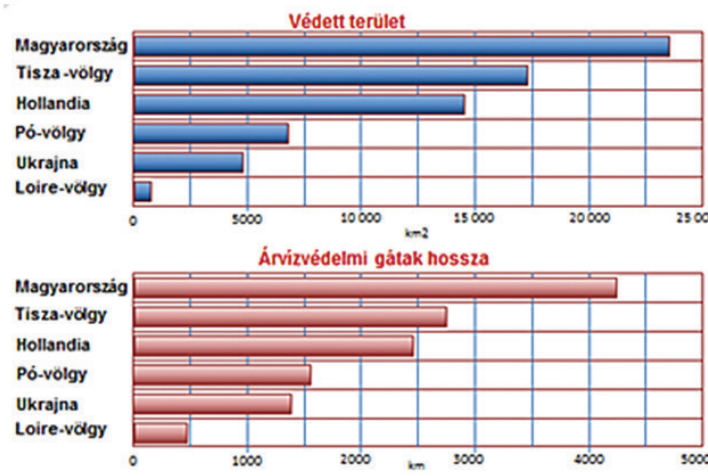

Forrás: NVS 2017

A belvíz a hazánk területének 45 százalékát kitevő lefolyástalan területeken okoz károkat főként a mezőgazdaságban, de településeket, közlekedési útvonalakat és iparterületeket is veszélyeztet, és közvetetten környezeti változásokhoz is hozzájárul, például a szikesedéshez. Az aszály föként az Alföldet és a Tisza vidékét súitja, ahol a párolgás több is lehet, mint az átlagosan előforduló csapadék. Az aszály károkozása elérheti, sőt meg is haladhatja az árvíz okozta károkat (3. ábra).

3. ábra: A vízproblémák halmozódása Magyarország területén

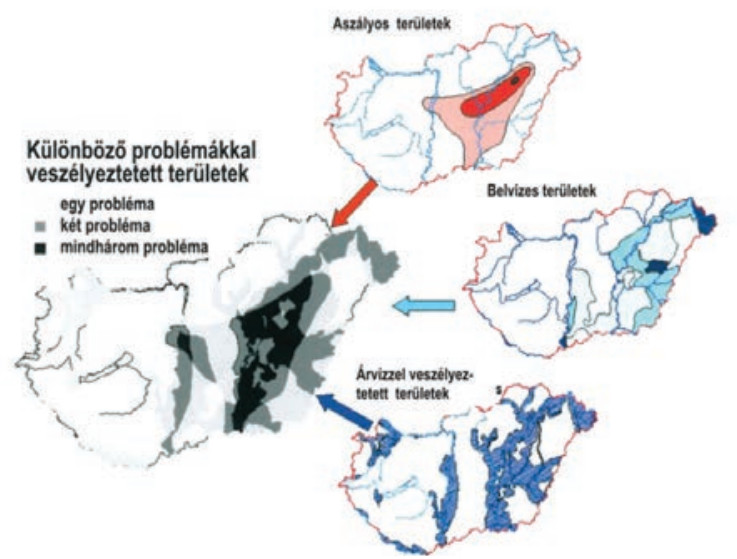

Forrás: Váradi 2011
A szélsőségek, az árvizek, belvizek, az aszály előfordulása természet- és társadalom-földrajzi adottságaink törvényszerü következményei. A küzdelem ellenük nem katasztrófaelhárítás, hanem a Kárpát-medence vízgazdálkodásának nagy szakmai felkészültséget igénylő, mindennapos üzemeltetési feladata, a vízválság megelözésének kulcsa.

Hazánk területén 145 állami tulajdonú, árvízvédelmi töltéssel védett ártéri öblözet található. Az ártéri öblözetek nyilvántartott teljes területe $21207 \mathrm{~km}^{2}$. Az ártéri öblözeteket a tizenkét vízügyi igazgatóság kezelésében levő 110 árvízvédelmi szakasz, összesen 4157,1 km árvízvédelmi töltés védi. Az árvizek elleni védelemre világviszonylatban eddig egyedülálló védelmi szervezettel, szakértelemmel és gyakorlottsággal rendelkezünk. (Európában is egyedülálló a védelmi rendszer, a vízügyi igazgatósági hálózat, a 150 éves védelmi tapasztalatokat feldolgozó védelmi tervek, a magas szakmai színvonalú előrejelző rendszer, védelmiszakasz-beosztás és osztagszervezettség, a hierarchikus irányítási és személyi felelősségi rendszer.)

A magyar árvízvédekezés szervezettsége és szakértelme felér egy fejlesztéssel. ${ }^{1}$ Jelzik ezt az elmúlt évized nagy védekezéseinek a sikerei a társadalom kiemelkedő összefogásával.

A pozitívumok mellett fóként finanszírozási hiányból fakadó gond, hogy az árvízvédelmünkre a katasztrófahelyzetek kezelése jellemző. A védekező szervezet gyengülő ütőképességének egyre súlyosabb tünetei a csökkenő szakemberlétszám, az elavuló és elöregedö védekezési technika, a fenntartás hiánya.

- A költséges árvízvédekezés finanszirozása a jellemző a megelözést szolgáló fejlesztések helyett.

Az országot az évszázados múltra visszatekintő, alapvetően a területvédelmet előtérbe helyező szabályozott vízállapotok jellemzik. A védettséghez hozzáidomult a területhasználat, ezen változtatni csak igen lassan és költségesen lehet. A különböző értékű területek védelmére az „egyenlő biztonság elve” ma még jogszabályi követelmény, természetes módon elvárt állami szolgáltatás. Az elsőrendü, állami kezelésű védvonalak által mentesített területeken esetlegesen bekövetkező károknál az állam áll helyt (lásd pl. a tarpai szakadás utáni helyreállítás). A szélsőségek gyakoribbá válása, a természetvédelem felértékelődése, a vízhez való hozzáférés azonban az évszázados védelmi rendszer megújítását sürgeti, úgy, hogy az adottságok és a használati elvárások közötti ellentmondások közben kiéleződnek.

Az árvizek kockázata az utóbbi időben - és valószínüsíthetően a jövőben is - nö a természeti folyamatok változásának és az emberi beavatkozások hatásainak következtében (4. ábra). Ennek oka többek között: 
- a klímaváltozás ${ }^{2}$

- a gyakran szük hullámterek,

- a nagyvizek (árhullámok) lefolyását képező akadályok, a folyók nagyvízi levezető képességének a romlása, árterek feliszapolódása,

- a természetes árvíz-visszatartási képesség területhasználat miatti csökkenése,

- $\quad$ az árvízvédelmi művek fenntartásának gyakori ellehetetlenülése,

- a kockázatnak kitett vagyon értékének, illetve sérülékenységének növekedése az ártéren (a mentett árteret jellemzően veszélymentesnek tekintik).

4. ábra: Árvízkockázatot növelö változások

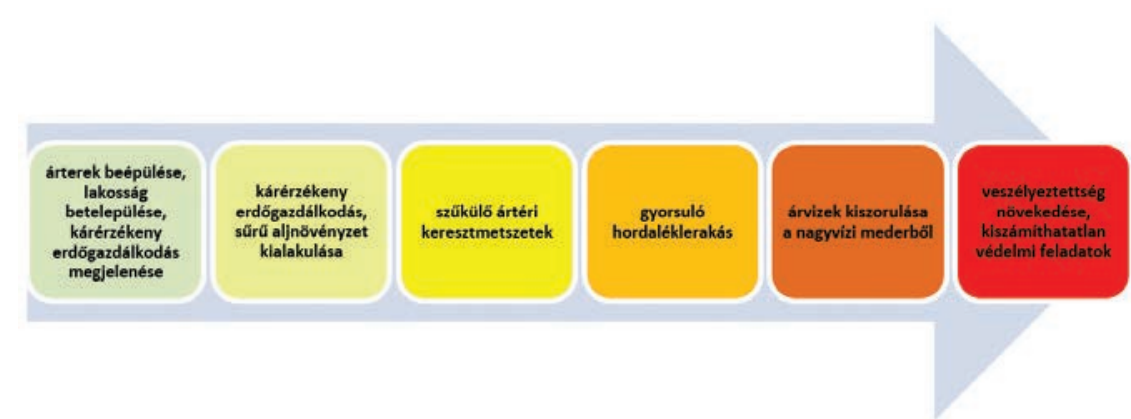

Forrás: Láng 2017

A rendkívüli árvizek történetében példátlan gyorsasággal egymást követő és a korábbiaknál rendre magasabb vízszinteket produkáló árvizeket mutatja, hogy az 1995 és 2015 közötti 20 évben több mint 64 helyen haladta meg az árvíz az addigi rekordokat, holott a megelöző 20 évben mindössze 10 helyen (5. ábra). Folyónként 64: Tisza 14, Duna 11, Hernád 8, Bódva 8, Zagyva 8 , Körösök 5, Rába 4, egyéb vízfolyásokon további 16 alkalommal történt az addig észlelthez képest magasabb vízállás.
5. ábra: Árvízi vízszintek 1975 és 2015 között

\section{20 év 1975-1995}

II. 20 év 1995-2015

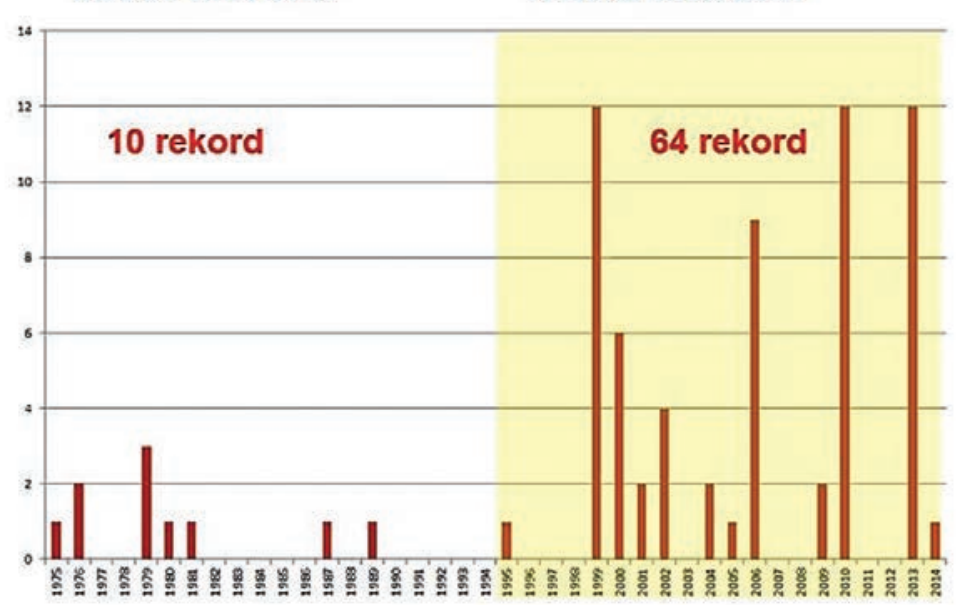

Forrás: Láng 2017

Hozzá kell, illetve lehet tenni, hogy a rendkívüli árhullámok elleni védekezés döntő többségében (a 2001. évi tarpai szakadás kivételével) sikeres volt, köszönhetően a harcedzett vízügyi irányítás szaktudásának és a hatalmas társadalmi összefogásnak. A folyamatot nézve és az eseményeket elemezve azonban egyértelműen megállapítható, hogy a hazai árvízvédekezés hagyományos eszközei kimerültek, a sikeres védekezés esélyének megőrzéséhez új eszközöket kellett keresni.

\section{Árvízi kockázatkezelés és az Európai Unió}

Az EU számos politikája hat közvetlenül a vizekre (például a közlekedéspolitika, benne is a vízi utak, a hajózás), de természeténél fogva a környezetvédelem tárgykörében kezelt vízpolitika a hangsúlyos, és ezt három felismerés határozza meg:

(1) az elmúlt másfél évszázad súlyos károkat okozott Európa vizeinek állapotában, különösen a vízi élővilágban, létszükséglet a romlás megállítása, illetve a helyreállítás.

(2) Az elmúlt évek nagy árvizei súlyos károkat okoztak egész Európában is. A velük való szembeszállás csak akkor lehet hatékony, ha az közösen, vízgyüjtöre orientáltan történik. Ezt célozza az Európai Parlament és a Tanács 2007/60/EK Irányelve az árvízi kockázatok felméréséről, értékeléséről és kezeléséről, az úgynevezett „árvíz-irányelv”.

(3) a tagállamok általösszehangolt, lehetőleg egységes problémaazonosításra, összevethető intézkedési tervekre és monitoringra van szükség. 
Az árvíz-irányelv a vizek fölös bősége miatti elöntések - árvizek, belvizek, völgyfenéki elöntések, villámárvizek - kezelését európai szinten kockázati alapokra helyezi. A koncepció tartalmazza az országos kockázatkezelési célkitűzéseket, alapelveket és prioritásokat, a kockázatkezelés rendjét, valamint a szükséges intézkedéseket. Az irányelv szerint:

- A területfejlesztéssel együttműködve elő kell mozdítania a vízzel, a földterülettel, a természeti erőforrásokkal és a természeti értékekkel kapcsolatos tevékenységek koordinált kezelését és megőrzését. Emiatt a tervezés során egymásra épülő, komplex megoldásokat kell keresni.

- Az árvízvédelmi biztonsági elöírásokat újra kell fogalmazni, ehhez

- A veszélyek elleni defenzív tevékenységröl át kell térni a kockázatok kezelésére, az ár- és belvízveszélyes területek hasznosításakor alkalmazkodni kell a fennálló veszélyekhez.

- Az árvizek és belvizek kezelése során, ahol ez lehetséges, a katasztrófamegelőzés elsődleges a katasztrófakezeléshez képest.

- Az árvízkockázat-kezelési tervek az integrált vízgyüjtő-gazdálkodás részét képezik. Az árvízkockázat-kezelési koncepció cél- és eszközrendszerének figyelembe kell vennie az észszerü és hatékony vízkészlet-gazdálkodás követelményét, illetve maga is ebbe az irányba kell, hogy befolyásolja a gazdálkodást.

- A megoldások megkövetelik az árvízi kockázatkezelési koncepció céljainak más szakpolitikákba történő integrálását. Különösen fontos az integráció az agrárpolitikába, a természetvédelembe, a környezetvédelembe, a területfejlesztésbe és a katasztrófavédelembe (például: vidékfejlesztés - vízvisszatartás, területfejlesztés - veszélyeztetettség). Ennek az alapja a prioritások újragondolása, illetve meghatározásuk érdekében az egyeztetési mechanizmusok javítása és korszerű döntés-előkészítési módszerek alkalmazása.

- A biztonsági előírások megfogalmazása során (1) az egyenlő biztonság elvén alapuló gyakorlatról való áttérést a kockázatkezelésre, az árvízveszélyes területek használatakor a fennálló veszélyekhez való alkalmazkodásra, a mérlegelt és differenciált biztonság elvére (2), a defenzív katasztrófakezelésről a megelőzésre való áttérést.

- A társadalom önvédelmi képességét erösíteni szükséges. Az a lakos vagy gazdasági szereplö, aki elszenvedheti egy elöntés következményeit, váljék alkalmassá (amennyire lehetséges) saját óvintézkedések megtételére a károk megelőzése, csökkentése érdekében.

Fontos követelmény tehát, hogy az árterületek hasznosításakor a társadalomnak és a gazdaságnak is alkalmazkodnia kell a területet érintő becsüllhető veszélyek szintjéhez. A tervezés során meg kell becsülni a társadalom számára elfogadható kockázat mértékét, miután az „abszolút biztonság” szintje nem elérhető, és célként racionálisan nem is közelíthető. Ehhez figyelembe kell venni, hogy a társadalom számára elfogadható kockázat meghatározásakor a nehezen vagy egyáltalán nem számszerüsíthető károkat is értékelni kell.

Az árvízkockázat-kezelési stratégia célja az is, hogy csökkentse az elöntési kockázatot akkor, ha az nagyobb az elvárt minimális szintnél, vagy ha az elfogadhatósági kereten belül a beavatkozás érdemi javulást okoz. Összességében elmondható, hogy az árvízzel és belvízzel veszélyeztetett területeken az elöntési károk kockázatát országosan csökkenteni kell, de a beavatkozások helyét és a csökkentés mértékét csak a jövőben, részletes vizsgálatok alapján lehet meghatározni.

$$
\text { Az árvízkockázat fogalma a kockázatkezelési térképezés során }
$$

Kockázat alatt az árvízi elöntésből fakadó hatások várható értékét értjük, azaz az elöntés előfordulási valószínűségének, a kitettségnek és a kitett értékek elöntéssel szemben való érzékenységének a szorzatát. Az előfordulási valószínűséget a veszély paramétereivel egyetemben (vízmélység, vízsebesség) a veszélytérképek tartalmazzák. A kitettség a vizsgált területen található vagyoni és nem-vagyoni értékek összessége (a területhasználati kategóriák szerint). Ezek érzékenységére utalnak a kárfüggvények és a nem-vagyoni értékek tekintetében az osztályba sorolás, azaz hogy adott tulajdonságú elöntés milyen mértékben károsítja a különböző értékeket. A kockázati térképek mint adatállományok e hatások területi eloszlását (50×50 méteres cellánként) mutatják be. Az összesített vagyoni kockázat 202943 millió Ft/ év. Kiemelt/összes életkockázati arány 10 százaléknál nagyobb 46 öblözetben, 40 százaléknál nagyobb 26 öblözetben.

A Duna „Első Árvízi Kockázatkezelési Tervét” 2016 februárjában fogadta el a 14 ország felelős vezetője. A magyar ÁKK a Duna-szintű tervben megfogalmazott elveket is átülteti a nemzeti viszonylatba. Magyarország Árvízi Országos Kockázatkezelési Tervét a kormány a 1146/2016. (III. 25.) határozatával fogadta el

\section{Árvízkockázat-kezelés a Nemzeti Vízstratégiában}

2014-ben a vízügyi ágazat elkezdte, és 2015 végére befejezte az általános gazdasági fejlődést segítő Kvassay Jenő Terv/Nemzeti Vízstratégia kidolgozását, mely az ország vízgazdálkodási stratégiájának megújítását célozza. A tervet a kormány 2017 márciusában elfogadta. E szerint az árvízkockázat-kezelési koncepció céljai és alapelvei általánosságban az alábbiak:

- A kialakított rendszernek a területfejlesztéssel együttműködve elő kell mozdítania a vízzel, a földterülettel, a természeti erőforrásokkal és a természeti értékekkel kapcsolatos tevékenységek koordinált kezelését és megőrzését. Ezért a tervezés során egymásra épülő, komplex megoldásokat kell keresni.

- Az árvízvédelmi biztonsági elöírásokat újra kell fogalmazni, ehhez a veszély elleni defenzív tevékenységről át kell térni a kockázatok kezelésére, az árvízveszélyes területek hasznosításakor pedig alkalmazkodni kell a fennálló veszélyekhez; az árvizek és belvizek kezelése során - ahol ez lehetséges - a katasztrófamegelőzés elsődleges a katasztrófakezeléshez képest.

- Az árvízkockázat-kezelési tervek az integrált vízgyűjtő-gazdálkodás részét képezik. Az árvízkockázat-kezelési koncepció cél- és eszközrendszerének figyelembe kell vennie az 
észszerü és hatékony vízkészlet-gazdálkodás követelményét, illetve maga is ebbe az irányba kell, hogy befolyásolja a gazdálkodást.

- A megoldások megkövetelik az árvízi kockázatkezelési koncepció céljainak más szakpolitikákba történő integrálását. Különösen fontos az integráció az agrárpolitikánál, a természetvédelemnél, a környezetvédelemnél, a területfejlesztésnél (például vidékfejlesztés vízvisszatartás, területfejlesztés - veszélyeztetettség).

A Nemzeti Vízstratégia a realitás talaján megállapítja, hogy az „abszolút biztonság” szintje nem érhetö el, racionális célként nem is közelíthetö, ehelyett meg kell határozni a társadalom számára elfogadható kockázat mértékét, ennek a fö szempontjai:

- A nehezen vagy egyáltalán nem számszerűsíthető károkat is figyelembe kell venni.

- Csökkenjen az elöntési kockázat akkor, ha az nagyobb az elvárt minimális szintnél, vagy ha az elfogadhatósági intervallumon belül a beavatkozás érdemi javulást okoz. Összességében elmondható, hogy az árvízzel veszélyeztetett területeken az elöntési károk kockázatát országosan csökkenteni kell, de a beavatkozások helyét és a csökkentés mértékét csak részletes vizsgálatok alapján lehet a jövőben meghatározni.

- A veszélyeztetett területek hasznosításakor a társadalomnak és a gazdaságnak is alkalmazkodnia kell a területet érintő becsülhető veszélyek szintjéhez.

- A társadalom önvédelmi képességét erősíteni kell. El kell érni, hogy az a lakos, gazdasági szereplö, aki elszenvedheti az elöntési események következményeit, alkalmassá váljon (ha ez lehetséges) saját óvintézkedései megtételére a károk megelőzése, csökkentése érdekében. Ezért az árvízi tudatosság szintjét emelö programokat kell kidolgozni és végrehajtani, a jó építési és egyéb gyakorlatokat el kell terjeszteni.

- A kockázatkezelésnél egymásra épülő komplex megoldásokat kell keresni, ennek keretében:

a) a védekezés mellett a veszély megelözésére is nagy hangsúlyt kell fektetni, a vizek lehetőség szerinti visszatartásával, a tározás növelésével,

b) az árvízkockázattal érintett területeken ösztönözni kell a területhasználat-váltást a természeti adottságoknak nem megfelelő területhasználatok esetében,

c) az árvizek idején jelentkező víztöbblet természetes öblözetekbe való kivezetésének és megőrzésének lehetőségét vizsgálni szükséges,

d) az élő rendszerek víztározási kapacitását jobban ki kell használni,

e) az árvíz gyors levonulását elősegítő ún. árvízi levezető sáv kialakítását és fenntartását a kockázatokat és veszélyeket figyelembe véve, az érintett értékek összevetésén alapuló kompromisszumokkal el kell végezni,

f) a megoldások között kell, hogy szerepeljenek az agrárgazdálkodásban található lehetőségek is, mint a víz területen való tartása [tározással, (öntöző)csatornákkal, beszivárogtatással] és a talajvízháztartás javítása,

g) a védekezési rendszer rugalmasságát olyan eszközökkel kell növelni, mint a mobil gátak használata,

h) fentiek kiegészülnek a nem-szerkezeti intézkedések államilag összehangolt rendszerével.

\section{A nagyvízi mederkezelés szïkségessége, lehetősége és haszna}

Miután a töltések további emelése sem gazdaságilag, sem árvízbiztonsági szempontból, sem településszerkezeti adottságok miatt nem járható út, a vonalmenti védekezés hagyományosnak tekinthető müszaki megoldása helyett, az úgynevezett területi védekezés módszere került elötérbe, azaz:

a kisebb vízhozamú folyók esetében már sikerrel alkalmazott árvízcsúcs-csökkentés (tározás) módszert kell alkalmazni a Tisza esetében is, továbbá

- az árapasztással egy időben és azonos rangon kezelve szükséges és lehetséges a Tisza medrében, a nagyvízi mederben az árvízi hozamok levezetésének a feltételeit helyreállítani, illetve javítani.

A nagyvízi meder fogalma és funkciója a vízgazdálkodásról szóló 1995. évi LVII. törvényben

Nagyvízi meder: a vízfolyást vagy állóvizet magában foglaló terület, amelyet az árvíz levonulása során a víz rendszeresen elborít, és amelyet a mértékadó árvízszint vagy az eddig előfordult legnagyobb árvízszint közül a magasabb jelöl ki.

Elsődleges rendeltetése a mederből kilépő árvíz és a jég levezetése.

A nagyvízi mederben fekvő ingatlan tulajdonosa, illetve használója a nagyvízi mederben mezőgazdasági művelést, erdőgazdálkodást vagy más tevékenységet kizárólag saját felelősségére, az árvizek levezetésének akadályozása nélkül, a környezet- és természetvédelmi, valamint a kulturális örökségvédelmi elöírások megtartásával folytathat. A nagyvízi mederben a termőföld védelméről szóló törvény szerinti, a termőföld más célú hasznosítását, valamint a föld művelési ágának megváltoztatását végrehajtani kizárólag az érintett folyószakaszmeder kezelőjének előzetes hozzájárulásával lehet. A nagyvízi mederben, illetve a parti sávban való elhelyezkedés tényét mint jogi jelleget a vízügyi hatóságnak az érintett ingatlanra vonatkozó jogerős határozata alapján az ingatlan-nyilvántartásba fel kell jegyezni.

Nagyvízi mederkezelés: a terület hasznosítása és használata, a terület felmérése és nyilvántartása, megóvása, őrzése, fenntartása érdekében végzett tevékenység. A folyók nagyvízi medrére vonatkozóan kezelési tervet kell készíteni, amely a nagyvízi mederben tevékenységet folytatókra kötelező. A kezelési tervet a vízügyi igazgatási szervek irányításáért felelős miniszter rendeletben állapítja meg. A vízügyi hatóság jogosult - a természeti és a környezeti veszélyeztetettség megelözése (így a nagyvízi meder vízszállító képességének megőrzése, az árvizek levezetésének biztosítása) érdekében - a nagyvízi mederben telekalakítási, illetőleg építési tilalmat elrendelni. A folyók nagyvízi medrére vonatkozó kezelési terv készítésének rendjére és tartalmára vonatkozó szabályokat a kormány állapítja meg. 
A folyók vízszállító képessége az 1998-ban kezdődő árvizes időszak hatására, különösen a 2001. évi tarpai szakadást követően került reflektorfénybe, amikor a kormányzat paradigmaváltást kezdeményezett a Vásárhelyi Terv Továbbfejlesztésének (VTT) a megindításával. Az árvízszintek akkori és azóta is bekövetkezett emelkedésére adott tudományos válaszok egyértelműen igazolják, hogy azok okozója az árvizek levezetéséhez szükséges területek szűkülése. A hazai szabályozás saját kockázatra lehetővé teszi a töltések közötti időszakosan árvízjárta területek hasznosítását, hiszen ez az ország 4 százalékát teszi ki, de hagyományosan tiltja ezeken a területeken az építést, és szabályokhoz köti a müvelési ág megváltoztatását.

Történelmi példa a nagyvízi mederben való tevékenységek szabályozására

A hullámtér „klasszikus” területe a magyar vízjognak. Már a vízjogról szóló 1885. évi XXIII. törvénycikk (és annak akkori kommentárja) leírják, hogy „, hazai mérnökeink is belátták....... hogy csak töltések emelése által az árviznek kitett területek bizton nem mentesithetök, hanem szükséges, hogy az árvizeknek rendes lefolyása biztosittassék...”. Ezért a törvény egyértelmüen rendelkezik, hogy „töltések közé fogott folyóknál”, mai fogalommal a hullámtéren, illetve a nagyvízi mederben megfelelő műszaki sávban a művelési módokat rendeleti úton határozzák meg, és ezen a területen a művelési ág megváltoztatása vízügyi hozzájárulással volt csak lehetséges.

Ezeken a területeken bekövetkezett árvízi károkért nem jár kártalanítás, biztosítása is kizárt. Ennek ellenére, vagy evvel visszaélve, az árvízvédelmi töltések között és nyílt ártereken igen nagy területeken felhagytak a szántóföldi és gondozott talajú gyümölcs (pl. dió) termelésével, valamint a gyepgazdálkodással, legeltetett állattartással. Ezeket erdők váltották fel, illetve nagy területeken invazív növényfajok hatalmasodtak el. Nagy területek védetté nyilvánításával - a kezelési korlátok miatt - az aljnövényzet elburjánzik, az ott lelassuló víz okozta hordaléklerakódás gyorsítja a medrek feltöltődését. A települések egyre közelebb húzódtak a folyókhoz, az eredetileg elöírásosan lábakra épített üdülők lassan beépültek, a telkeket kerítésekkel vették körül.
6. ábra: Árvízi hurokgörbe (a vízállás és a vízhozam összefüggése) a Tisza szolnoki szelvényében 1895-2006 közötti nagyobb árvizek esetén

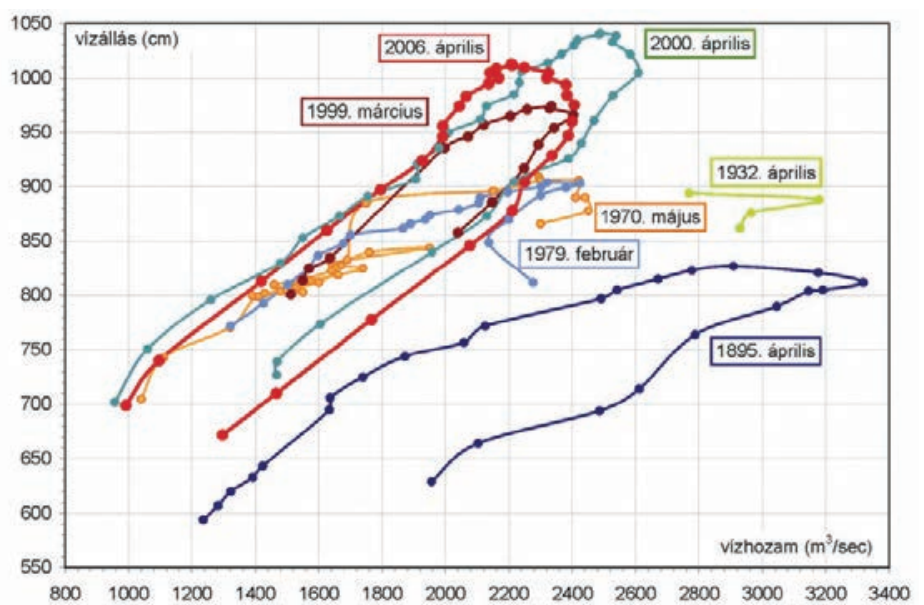

Forrás: ReWe Bt 2006

Az eredmény, amit a 6 . ábra is mutat: azonos vízhozamok mellett egyre emelkedő tetőző vízszintek állnak elő, ugyanis a szűk, beépített hullámtéren a rossz lefolyási körülmények visszaduzzasztást eredményeznek. Az árvízszintek ma már mintegy 1,5-2 méterrel haladják meg a 20. század derekáig észlelt maximumokat. Ez azt is jelenti, hogy a védvonalak jogszabálynak megfelelő kiépítettsége - az úgynevezett „mértékadó árvízszint” kényszerű megemelése miatt - 67 százalékról kevesebb mint 10 százalékra csökkent. A 20. század második felében megépült védvonalak, melyek bekerülési értéke mai áron meghaladja az 1500 milliárd forintot, eredeti funkciójukat elvesztették, a biztonságot ma már nem tudják szavatolni.

Ha ez a folyamat nem áll meg, a nagyvízi meder területe folyamatosan nőni fog, és az árvizek a töltések magassági biztonságának csökkenése miatt növekvő veszélyt jelentenek a védett településekre. Ha nem sikerül gátat vetni a folyók nagyvízi medrében a vízszállító képességet csökkentö, duzzasztást okozó tevékenységeknek (beépités, szántók megmüveletlensége, erdők aljnövényzetének elburjánzása stb.), akkor megállithatatlan és beláthatatlan az árvizek szintjének további emelkedése.

Annak érdekében, hogy a bekövetkező kár mérsékelhetővé váljék, nem elegendőek (és nem finanszírozhatóak) a hagyományos fejlesztések (töltés vagy tározóépítés), szükség szerint változtatni kell a területhasználatokat. 
A nagyvízi meder vízszállító képességével kapcsolatos beavatkozások, illetve tevékenységek az alábbi részekre oszthatóak:

- Az árvízlevezetés feltételeinek helyreállítására (szükséges mértékű javítására) irányuló beavatkozások, ezek lehetnek:

Müszaki beavatkozások - az ezekkel kapcsolatos eljárás a vízjogi engedélyezés rendjében szabályozva van.

- A nagyvízi mederben folyó, a vízszállító képességre kedvezőtlenül ható területhasználat megváltoztatása nem müszaki beavatkozással, hanem területhasználat-váltással - az ezekkel kapcsolatos eljárás szabályozatlan, illetve csak a törvényi alapjai vannak meg, a részletes szabályozás hiányzik.

A jogszerűtlen területhasználat megszüntetésének kikényszerítésével - az ezekkel kapcsolatos eljárás csak részben szabályozott, és a meglevő szabályok érvényesítése indokolatlanul nehézkes.

- A meder vízszállító képességének fenntartására irányuló beavatkozások, annak érdekében, hogy a nagyvízi meder területének használatában folyamatosan tudatosuljanak és érvényesíthetőek legyenek azok a követelmények, amelyeket a vízvezetés érdekében meghatároztak (pl. a megtisztított „elsődleges árvízi lefolyási sávok" oly módon történő használata/művelése, hogy tartósan akadálymentes maradjon). Az ezekkel kapcsolatos eljárásnak ma is több eszköze van (művelési kötelezettség, szabálysértési eljárás stb.), de nincsenek rendszerbe foglalva, gyakorlati szempontból sokszor végrehajthatatlanok, ellenőrzésük megoldatlan.

A fenti szabályozatlanságok megszüntetése során a nagyvízi meder következő (7. ábra) fö funkcióira kell különös tekintettel lenni:

- Folyóink és különösen a nagyvízi medrek természeti adottságai kimagasló értékűek (még akkor is, ha egyes, ma „természetesnek” minősülő vízfolyásunk mesterséges, ásott mederben kezdte újkori életét). Indokolt természetvédelmi követelmény, hogy ezeken a területeken természetszerű állapot uralkodjék; legyenek túlsúlyban az őshonos fajok alkotta társulások, maradjanak fenn a vizes élőhelyek (holtágak, anyaggödrök), állandóan fenntartott, folyamatos zöldfolyosó biztosítsa a migráció lehetőségét.

- A szociális jellegü igények (üdülés, hobbikertészkedés, zöld turizmus, vízi sport, fürdőzés, stb.) erőteljesen növekednek, és a környező lakosság gazdasági gyarapodásának is jelentős tényezői.

- Számottevő a gazdasági hasznosítás igénye, mind a növény- és állattenyésztést, mind az erdőgazdálkodást illetően. 7.ábra: A nagyvízi meder sematikus rajz

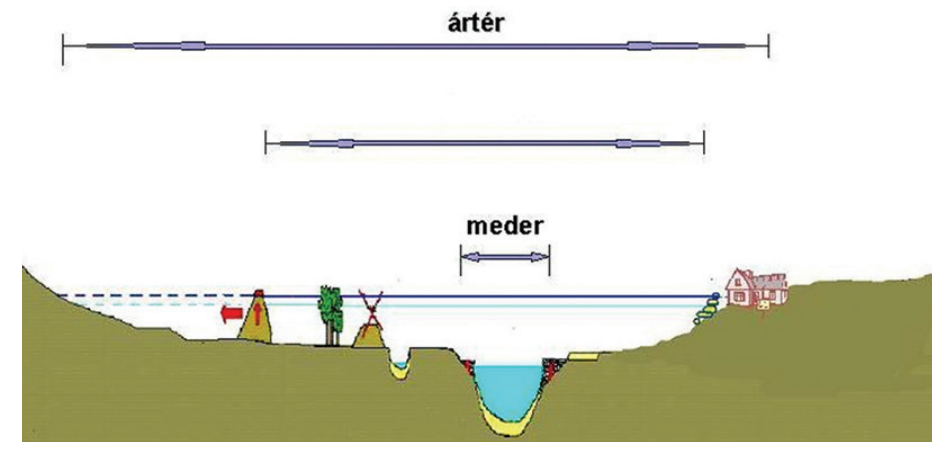

Forrás: ReWe Bt 2008

Ezek a funkciók gyakorta kerülnek konfliktusba a nagyvízi meder árvíz-levezetési funkciójával. A konfliktusok forrása egyfelől a folyó egységének, másfelől a használók, illetve a kezelők elkülönültségének ellentmondása. Ezért a nagyvízi mederkezelés problematikáját, ami csak integrált gazdálkodással oldható fel, társadalmilag nyílt tervezéssel vizsgáltuk. Olyan igénykielégítési és érdekegyeztetési metódus szükséges ugyanis, amelynek alkalmazásával lehetővé válik a folyók élettér-alakító és emberi szükségleteket kielégítő szerepének fenntartása. A közösségi döntés-előkészítési eljárás keretében valamennyi érdekelt egyezkedésével alakulhat ki az egységes - integrált értékmérleg, és ennek eredménye szolgál alapul a használati, valamint a mederkezelési feladatok megfogalmazásához és a végrehajtás módjának kiválasztásához.

A nagyvízi medrek, a parti sávok, a vízjárta, valamint a fakadó vizek által veszélyeztetett területek használatáról és hasznosításáról, valamint a nyári gátak által védett területek értékének csökkenésével kapcsolatos eljárásról szóló 21/2006. (I. 31.) Korm. rendelet a fentiek fó kereteit határozza meg.

Ugyanakkor a gyakorlat bebizonyította, hogy az általánosan érvényes normatív szabályok „nem elég finomságúak” a nagyvízi mederben érvényesülő bonyolult érdekek mérlegeléséhez, a nagyon változatos morfológiai és egyéb adottságokhoz. Ilyen például, hogy a nagyvízi mederből kiemelkedő, a víz által soha birtokba nem vett területrészek között nem képes differenciálni - pedig indokolt, hogy ilyen helyeken más területhasználati szabályok érvényesüljenek. Hasonlóképpen hiányzik az árvízlevezetés szempontjából fontos és kevésbé fontos területrészek - levezető sávok - megkülönböztetésének (zonáció) lehetősége. 
Levezető sávok: a nagyvízi meder azon részei, amelyek az árvíz és a jég elvezetésében részt vesznek, ezek:

I. Elsődleges levezető sáv - maga a meder vagy a meder mellett lévő nyílt terület, amely a keresztmetszetéhez képest rendkívül nagy mennyiségű vizet szállít árvíz idején. Itt kizárt vízhasználathoz közvetlenül nem kötődő építmény építése és felújítása is.

II. A másodlagos levezető sáv - még jelentős hozamot szállít, ahol a meglévő épület felújítása támogatható, de alapterületének növelése nem.

III. Átmeneti levezető sáv - időszakosan elöntésre kerülő terület, az árvíz levezetésében még részt vesz, de szerepe nem jelentős, ezeken a területeken külön engedéllyel az építmény bővítése is lehetséges.

IV. Áramlási holtér - árvízlevezetés szempontjából bármi építhető, amennyiben a tulajdonos türi az elöntést.

A nagyvízi medrekben ma 15.467 (!!) épület van. A fenti elvet követve 88 százalékuk (13.576 épület) a jelenlegi merev tiltásnál kedvezőbb helyzetbe kerül. Az elsődleges levezető sávban levő 122 épületből 107 egy tömbben van a Közép-Tisza-vidéki területen. Másodlagos sávban ugyancsak tömbben helyezkedik el 1339 (a Közép-Dunán, a Felső-Tisza-vidéken, valamint az Alsó-Tisza-vidéken). Ezek ütemezési és műszaki tekintetben sajátos kezelést igényelnek, illetve kapnak. Így mindössze 430 épület - a nagyvízi mederben ma elhelyezkedők 2,8 százaléka - marad a legszigorúbb tiltás kategóriájában, de ezek mindegyikét el is öntötték az elmúlt évek árvizei, tehát a tulajdonosok által ismert tények rögzítése fog történni.

A gyakorlat számára régóta hiányzott az ilyen „finom” megkülönböztetéseket, az előírások elvszerű helyre adaptálását lehetővé tevő eszköz (8. ábra). Ezt a célt szolgálja a vízgazdálkodásról szóló törvény által előirányzott „nagyvízi mederkezelési terv” intézményének a szabályozása. Ennek megalkotása egyben lehetőséget ad az előbb említett rendelet finomhangolására is. Így lehetővé válik a kötöttségek észszerű differenciálása, adott esetben enyhítése a jelenlegi helyzethez képest.
8. ábra: Zonáció a nagyvízi mederben

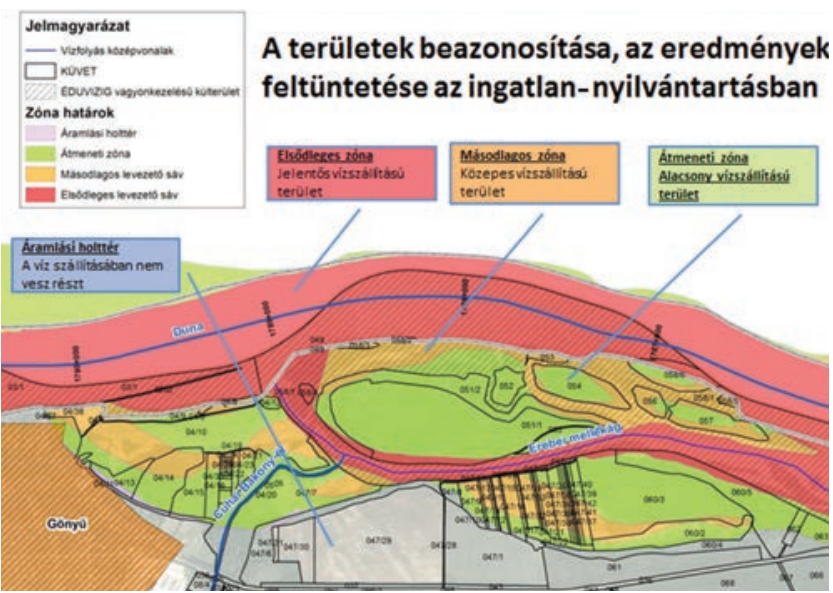

Forrás: Láng 2016

A nagyvízi meder kezelésének célja, hogy a folyó:

ne okozzon az érintett lakosság számára vállalhatatlan élet- és vagyonkockázatot;

- maradjon természetes élőhely és tájalkotó érhálózat;

- l legyen forrása a társadalom anyagi és szociális szükségletei kielégítésének.

A nagyvízi medernek mindezekért alkalmasnak kell lennie:

- természetes hidrológiai szerepére, a víz, a jég és a hordalék levezetésére;

- a tájban honos flóra és fauna számára élőhely biztosítására

- a víz és a partok emberi használatára.

A nagyvízi mederkezelési tervek jelentik az eszközt arra, hogy az egyes mederszakaszokon felesleges, merev jogszabályi előírások alól mentességet biztosítsanak annak érdekében, hogy az újragondolt árvízvédelmi stratégiának megfelelően az árvízvédelmi töltések védképességének állandó fejlesztése helyett a hullámterek, nyílt árterek észszerű hasznosítása során a terület kárérzékenységét a minimálisra csökkentsük. A nagyvízi mederkezelési tervek arra is lehetőséget adnak, hogy kiemelkedő társadalmi jelentőségű hely (természetvédelmi érték, műemlék, üdülőterület stb.) esetében, legyen lehetőség alternatív kompenzáló intézkedésekre, amelyekkel elérhető, hogy az árvízszintek ne emelkedjenek, de a megvédendő érték se sérüljön.

Mindezek mellett és ellenére, nyilván nem az elsődleges levezető sávban, de fog maradni a nagyvízi mederben - különösen az árvízszintek további emelkedése esetén - épület (lakó, üdülő, termelő stb.). Ezek esetében egyre fontosabbá válik az 
objektumvédelem, valamint eszközeinek a fejlődése, illetve támogatása is. Azokban az országokban, ahol például völgyfenéki településeken megszokott jelenség az épületek elöntése, erre már szinte külön ipar kezd kialakulni vízzáró nyílászárók, csatorna-visszacsapó szelepek, vízálló vakolatok és a víz elleni védelemre hivatott egyéb eszközök gyártására, forgalmazására, a használatukkal kapcsolatos tanácsadásra. Az ilyen eszközöknek nemcsak árvízveszélyes területeken, hanem belvízjárta területeken is van létjogosultságuk. Ez már mind létszámban, mind jellegében olyan lakossági ügy, amely joggal vet fel biztosítási megfontolásokat is.

A mai „veszélyhelyzet-kezelő” árvízvédelem finanszírozása (védekezés, helyreállítás, kártérítés, kártalanítás) - jellegénél fogva - lökésszerűen, tervezhetetlenül jelenik meg a költségvetésben. Árhullámról árhullámra milliárdokat költünk a védekezésre és helyreállításra, evvel együtt a kárérték minimum évi 1 százalékkal növekszik. A megelőző jellegű árvízkockázat-kezelés elvárt eredményének kell lennie annak is, hogy ez a terhelés „kisimuljon”. Mi ez, ha nem biztosítási eset: tartalékképzés a véletlenszerűen (bizonyos valószínűséggel) bekövetkező káreseményekre?

Hazánkban is történt erre kísérlet a Wesselényi Alappal. Ma persze a biztosítók a hullámtérben fekvést, az ottani elöntés révén bekövetkező árvízkárt nem véletlenszerü eseménynek tekintik, hanem biztosan bekövetkezőnek. Vannak azonban olyan nemzetközi példák, ahol ebben a „kisimításban” a biztosító szektor sikeresen közreműködik. Franciaországban például egy összetett rendszer működik az állam, a biztosítók és az állam által létrehozott nemzeti viszontbiztosító részvételével. A viszontbiztosító forrásául az ingatlankárokra kötött biztosítások díjának egy fix százaléka szolgál. Ez az alapja a károsultak kárenyhítésének minden olyan esetben, amelyet az állam természeti katasztrófának minősít. A kárenyhítés mértéke a biztosítókkal kötött szerződéseken alapul. A szolidaritási alapnál a biztosítók is viszontbiztosíthatják magukat nagyon nagy katasztrófák esetére.

Ez a példa, de még inkább az előttünk álló feladatok azt igazolják, hogy a vízügynek és a biztosító szakmának érdemes, hasznos lenne kiterjedtebb, szakmai tudományos alapon zajló párbeszédet folytatnia.

\section{HIVATKOZÁSOK}

'A Halcro-Water cég magyarországi árvízfejlesztésekről készített tanulmányának megállapítása, 2007.

¿A klimaváltozás árvízi kockázatot nơvelő hatása a villámárvizeknél egyértelműnek tűnik. A nagy folyókon jóval nagyobb a kockázat bizony ar

\section{IRODALOMJEGYZÉK}

Nemzeti Vizstratégia - Kvassay Jenỏ Terv (NVS) 2017. http://www.kormany.hu/hu, illetve megalapozó háttértanulmánya, 2015. http://www.vizugy.hu/ utolsó letöltés 2017.05.08. . Ungvari Gabor - Kis Andras: Tobbletterületek biztositasa az a rvvizkockazat-csökkentés érdekében. Az Európában alkalmazott megoldások áttekintése, BCE-REKK 2013 